\title{
Chemical modification of L-glutamine to alpha-amino glutarimide on autoclaving facilitates Agrobacterium infection of host and non-host plants: A new use of a known compound
}

\author{
Indra Sandal ${ }^{1 \dagger}$, Amita Bhattacharya ${ }^{4 *}$, Uksha Saini $^{2 \dagger}$, Devinder Kaur ${ }^{4}$, Shveta Sharma ${ }^{4}$, Ashu Gulati ${ }^{4}$, \\ Jonnala K Kumar ${ }^{3}$, Neeraj Kumar ${ }^{4}$, Jyotsna Dayma ${ }^{4}$, Pralay Das ${ }^{4}$, Bikram Singh ${ }^{4}$ and Paramvir S Ahuja ${ }^{4}$
}

\begin{abstract}
Background: Accidental autoclaving of L-glutamine was found to facilitate the Agrobacterium infection of a non host plant like tea in an earlier study. In the present communication, we elucidate the structural changes in Lglutamine due to autoclaving and also confirm the role of heat transformed L-glutamine in Agrobacterium mediated genetic transformation of host/non host plants.

Results: When autoclaved at $121^{\circ} \mathrm{C}$ and 15 psi for 20 or 40 min, L-glutamine was structurally modified into 5-oxo proline and 3-amino glutarimide ( $\alpha$-amino glutarimide), respectively. Of the two autoclaved products, only $\alpha$-amino glutarimide facilitated Agrobacterium infection of a number of resistant to susceptible plants. However, the compound did not have any vir gene inducing property.

Conclusions: We report a one pot autoclave process for the synthesis of 5-oxo proline and $\alpha$-amino glutarimide from L-glutamine. Xenobiotic detoxifying property of $\alpha$-amino glutarimide is also proposed.
\end{abstract}

\section{Background}

Glutarimides are the hydrolyzed cyclic imides formed as a result of cyclization of glutamine. These compounds particularly, the $\alpha$-amino glutarimides are important components of many extremely valuable drugs. The glutarimide moiety is present in a great number of molecules and has a broad spectrum of pharmacological activities. Many glutarimides have been reported to show notable anticancer activity, cytotoxicity against $\mathrm{KB}$ cells in vitro, and are also potent inhibitors of P388 murine leukemia in vivo [1]. Since aminoglutethimide inhibits steroidogenesis at the aromatase sites, it is used in treating metastatic breast cancer [2]. Antineoplaston A10 (N-[(3S)-2,6-dioxo-3-piperidyl]-2-phenyl-acetamide) is another glutarimide derivative, originally isolated from human urine. It has remarkable anticancer activity but

\footnotetext{
* Correspondence: amitabhatta@ihbt.res.in

+ Contributed equally

${ }^{4}$ CSIR-Institute of Himalayan Bioresource Technology, Council of Scientific

and Industrial Research, Palampur-176061, H. P. India

Full list of author information is available at the end of the article
}

lacks the toxicity of other common cancer drugs [3]. It has been suggested that A10 acts directly at the genomic level and alters the cellular responsiveness to steroidal hormones [4]. Thalidomides have special clinical value in a number of pathological conditions such as erythema nodosum leprosum, rheumatoid arthritis, HIV-associated oral ulcers, and chronic graft versus host diseases [5]. Both in vitro and in vivo studies have shown that thalidomides have the ability to inhibit tumor necrosis factor- $\alpha$ and its production [6]. FDA has approved this drug for the treatment of erythema nodosum leprosum (ENL) and multiple myeloma [7]. Many glutarimide derivatives are partial agonists of the central nervous system (CNS) and their actions range from convulsive and analeptic (agonist) to anticonvulsive and hypnotic (antagonist). The importance of glutarimide moeties in antibiotics such as the cycloheximides is well known and they act by inhibiting the synthesis of bacterial peptides at the initiation and extension steps [8]. However, the present study elucidates and reports a new function of $\alpha$-amino glutarimide as a potent facilitator 
of Agrobacterium infection of generally resistant host plants. The study also shows that $\alpha$-amino glutarimide is a major product formed as a result of chemical modification of L-glutamine upon autoclaving.

Infection of target host and non host plants by engineered Agrobacterium tumefaciens is required for the production of tailor made transgenic plants expressing useful yield and quality enhancing genes [9]. As compared to direct transformation methods, Agrobacterium mediated genetic transformation allows higher frequency of stable transgene expression $[10,11]$. Hence this method has been employed to produce a large number of transgenic plants till date. Even the natural barriers that prevent the use of Agrobacterium as a vector for genetic transformation of monocots have now been overcome through the use of several innovative approaches, and several crop plants have been successfully transformed [11-16]. Yet, quite a good number of crops, particularly, several important ones that exude bacteriostatic or bactericidal leachates as plant defense have remained outside Agrobacterium's host range, and gene transfer into them is largely difficult. It is while targeting such 'difficult to transform crops' for transgenic production by Agrobacaterium tumefaciens, that $\alpha$-amino glutarimide can prove extremely useful.

\section{Methods}

Aqueous solution of L-glutamine at a concentration of $2.0 \mathrm{~g} \mathrm{litre}^{-1}$ (Sigma, India) was autoclaved at $121^{\circ} \mathrm{C}$ and 15 psi for 20 and 40 minutes and lyophilized to afford $\mathrm{GlA}_{20}$ and $\mathrm{GlA}_{40}$, respectively. The same concentration of aqueous L-glutamine solution that was not autoclaved but filter sterilized served as control (GFs).

\section{Chemical characterization of autoclaved products}

$\mathrm{GlA}_{20}, \mathrm{GlA}_{40}$ and control were subjected to TLC in order to study the structural changes in L-glutamine due to thermal degradation by autoclaving. Samples spotted on TLC plates were run in solvent systems comprising of butanol:water:acetic acid:: 4:1:5 and n-propanol:2-propanol:water:: 4:3:2 followed by heating at $300^{\circ} \mathrm{C}$ in an oven for 15 minutes. Visual changes in color and $R_{f}$ values of the spots were noted after spraying ninhydrin reagent on chromatographed TLC plate.

The autoclaved samples $\left(\mathrm{GlA}_{20}\right.$ and $\left.\mathrm{GlA}_{40}\right)$ were also characterized by modern spectroscopic techniques i.e. NMR and ESI-MS. NMR spectra were recorded on a Bruker Avance-300 spectrometer. Mass spectra were recorded on QTOF-Micro of Waters Micromass.

\section{Agrobacterium growth in response to autoclaved products}

The engineered Agrobacterium tumefaciens strain, GV3101 containing the plasmid p35SGUSINT with the gus reporter and nptII selection marker genes was used. To fresh cultures of this strain harvested at an optical density (OD) of 0.6 at $\mathrm{A}_{600} \mathrm{~nm}, 2.0 \mathrm{~g}_{\text {litre }}{ }^{-1}$ of $\mathrm{GlA}_{20}$, $\mathrm{GlA}_{40}$ and GFs (as standardized in an earlier study) were added and grown overnight as shake cultures in 20 $\mathrm{ml}$ Yeast Mannitol Broth (YMB) in dark at $28^{\circ} \mathrm{C}$ and $150 \mathrm{rpm}$ for $24 \mathrm{hrs}$. In another experiment, freshly revived cultures of $A$. tumefaciens was grown in liquid basal MS medium [17] containing either of $2.0 \mathrm{~g} \mathrm{l}^{-1}$ GFs, $\mathrm{GlA}_{20}, \mathrm{GlA}_{40}$ maintained at different $\mathrm{pH}$ i.e., 5.2, 5.6, 5.9 and 7.0. Growth in response to $2.0 \mathrm{~g} \mathrm{l}^{-1} 5$-oxo proline (purchased from Sigma, USA) in MS and YMB was also tested at these pHs. All the results were confirmed using 1.5\% agar solidified YMB and MS medium.

For each of these experiments, cultures grown in medium free of GFs, $\mathrm{GlA}_{20}, \mathrm{GlA}_{40}$ or 5-oxo proline served as control. A minimum of three replicates per treatment were used. Growth in each case as represented by population density (i.e., a value $=$ optical density $(\mathrm{OD})$ at $\mathrm{A}_{600} \mathrm{~nm} \times 1 \times 10^{9} \mathrm{cfu} \mathrm{ml}^{-1}$ ) was measured at regular 12 hr interval for 24 and 48 hrs of incubation in case of liquid and solid media, respectively.

\section{Agrobacterium virulence (vir) gene induction assay}

Vir gene induction by the autoclaved products was tested using an octopine-type Agrobacterium strain A348 harboring the pSM219 plasmid with lacZ under the control of virH promoter in trans to the wild-type pTiA6 plasmid $[18,19]$. $\mathrm{GlA}_{20}, \mathrm{GlA}_{40}$ or GFs were added to overnight grown bacterial cultures in YMB. The reporter $\beta$-galactosidase activity was measured, and the results were expressed in specific units calculated as described [18-20]. The popular vir gene inducer AS (100 $\mu \mathrm{M})$ was used as a positive control for its maximal vir gene induction ability.

\section{Facilitation of Agrobacterium infection of plants by the autoclaved products of L-glutamine}

The effect of $\mathrm{GlA}_{20}, \mathrm{GlA}_{40}$ or GFs on Agrobacterium infection of plants was tested using tender leaves of a number of plant species like Podophyllum hexandrum (Indian may apple), Aloe vera (aloe), Lavendula officinalis (lavender), Rosa sp. (wild rose), Malus domestica (apple) rootstock MM106, Dendrocalamus asper (bamboo), Cynodon dactylon (grass), Zea mays (maize), Oryza sativa (rice), Triticum aestivum (wheat), Aurocaria (ornamental gymnosperm) and Dryopteris (fern). The leaves of Nicotiana tabacum (tobacco) served as control.

All the leaves were washed with Tween 20 and surface sterilized using $0.01 \%$ mercuric chloride for 5-10 min followed by thorough rinsing in sterile de-ionized water to remove all traces of mercuric chloride. The surface sterilized leaves were immersed for $10 \mathrm{~min}$ in fresh 
overnight grown culture of A. tumefaciens strain GV3101 and co-cultivated for 1, 2, 3, 5, 6 and 8 days at $28^{\circ} \mathrm{C}$ in dark after blotting off excess bacteria. Basal MS medium containing $2.0 \mathrm{~g} \mathrm{l}^{-1}$ of either of $\mathrm{GlA}_{40}, \mathrm{GlA}_{20}$, 5-oxoproline and GFs was used for co-cultivation. After each co-cultivation period, cefotaxime at $1 \mathrm{~g} \mathrm{l}^{-1}$ was used to wash the explants free of all residual Agrobacterium which were cultured on basal MS medium containing $5 \mu \mathrm{M}$ TDZ and $10 \mu \mathrm{M}$ NAA (MSC) at $\mathrm{pH} 5.6$ under culture lab conditions for callus formation. In order to identify the optimal conditions, different $\mathrm{pH}$, i. e., 5.2, 5.6, 5.9 and 7.0 of the co-cultivation medium containing $2.0 \mathrm{~g} \mathrm{l}^{-1}$ of $\mathrm{GlA}_{40}$ were also tested.

In another experiment, leaves of different plant species (tobacco, Indian may apple, aloe, lavender, wild rose, apple rootstock MM106, bamboo, grass, maize, rice, aurocaria and fern) were also transformed using different densities of Agrobacterium equivalent to $1 \times 10^{7}, 1$ $\times 10^{8}, 1 \times 10^{9}$ and $1 \times 10^{10} \mathrm{cfu} \mathrm{ml}^{-1}$ at $\mathrm{A}_{600} \mathrm{~nm}$. These were then co-cultivated on medium supplemented with either of GFs, $\mathrm{GlA}_{40}, \mathrm{GlA}_{20}$ or 5-oxo proline at pH 5.6.

Agrobacterium infected explants co-cultivated on medium containing $100 \mu \mathrm{M}$ AS but free of GFs, GlA 40 , $\mathrm{GlA}_{20}$ or 5-oxo proline supplements served as positive control. A minimum of five replicates with three leaves per plant species were taken for each experiment which were repeated at least thrice.

\section{GUS assay}

The histo-chemical assay of Jefferson et al. [21] was used to assess the success of transgene delivery into explants. After 1, 2, 3, 5, 6 and 8 days of co-cultivation, explants, treated (co-cultivated on media containing GFs, $\mathrm{GlA}_{40}, \mathrm{GlA}_{20}$ or 5-oxo proline at different $\mathrm{pH}$ ) and control (co-cultivated on media containing $100 \mu \mathrm{M}$ AS but free of either $\mathrm{GlA}_{20}, \mathrm{GlA}_{40}$, GFs or 5-oxo proline) were randomly selected and immersed in assay buffer containing 5-bromo-4-chloro-3-indolyl- $ß-\mathrm{D}$-glucuronide (GUS) followed by vacuum infiltration for 15 minutes. After an overnight incubation in dark at $37^{\circ} \mathrm{C}$, the expression of gus reporter gene was scored as blue spots and/or sectors per leaf explant and photographed using a Sony Cybershot DSC-F-828 camera. GUS assay was also done for the leaf explants transformed using different densities of Agrobacterium followed by co-cultivation on medium containing GFs, $\mathrm{GlA}_{40}, \mathrm{GlA}_{20}$ or 5-oxo proline as well as control.

\section{PCR confirmation of genetic transformation}

Callus tissue formed on the leaf explants of different plant species transformed in the presence and absence of either GFs, $\mathrm{GlA}_{40}, \mathrm{GlA}_{20}$ or 5-oxo proline were selected on MSC containing $100 \mu \mathrm{g} \mathrm{ml}^{-1}$ kanamycin. As described by Doyle and Doyle [22], total genomic DNA was extracted from the kanamycin resistant calli (500 $\mathrm{mg})$. These were PCR amplified using 35 cycles of denaturation at $94^{\circ} \mathrm{C}$ for $1 \mathrm{~min}$, annealing at $55^{\circ} \mathrm{C}$ for $1 \mathrm{~min}$ and extension at $72^{\circ} \mathrm{C}$ for $2 \mathrm{~min}$ followed by further extension cycle of $7 \mathrm{~min}$ at $72^{\circ} \mathrm{C}$ using a programmable Stratagene Robocycler Gradient 40. The isolated genomic DNA (50 ng) was amplified using $200 \mu \mathrm{M}$ dNTPs, $1.5 \mathrm{U}$ Taq DNA polymerase and 10 pmol of forward and reverse primers i.e., 5'-GGTGGGAAAGCGCGTTACAAG-3' and 5'-TGGATCCCGGCATAGTTAAA-3', respectively (Bangalore Genei, India) designed so as to amplify a $490 \mathrm{bp}$ fragment of the gus gene). While $50 \mathrm{pg}$ of plasmid DNA served as positive control, DNA from untransformed tissues were used as negative controls. The amplified products were finally resolved on $1.2 \%$ agarose gel using a 0'GeneRuler ${ }^{\mathrm{TM}} 100$ bp plus DNA ladder from Fermentas, Life Sciences. Plant species (eg. Podophyllum and Aurocaria) that failed to produce leaf callus were not subjected to PCR.

\section{Southern hybridization}

Genomic DNA was isolated from callus tissues of different plant species transformed in presence and absence of $\alpha$-amino glutarimide. The isolated DNA $(10 \mu \mathrm{g})$ were digested with HindIII and EcoRI (New England Biolabs Inc. USA) and resolved on $0.8 \%$ agarose gel along with a 0'GeneRulerTM 100 bp plus DNA ladder (Fermentas, Life Sciences). This was then blotted onto a nylon membrane (Hybond-N, Amersham Biosciences, Little Chalfont, Buckinghamshire, UK) and hybridized with PCR amplified plasmid gus gene probe labeled with Biotin using Biotin DecaLabel DNA Labeling kit, Fermentas, Life Sciences. The chromogenic substrate BCIP/NBT (nitro blue tetrazolium chloride/5-bromo-4-chloro-3indolyl phosphate, toluidine salt) was used to detect the hybridization products of the biotinylated probe and the streptavidin-alkaline phosphatase conjugate as blue-purple colored bands.

\section{Results}

Chemical characterization of autoclaved products

The yield of $\mathrm{GlA}_{20}$ and $\mathrm{GlA}_{40}$ was found in the range of 92-95\%. While $\mathrm{GlA}_{20}$ was observed in white crystalline powder, $\mathrm{GlA}_{40}$ was a creamy white powder. The latter was highly hygroscopic and turned into a pale yellow sticky mass within an hour under ambient conditions.

\section{Thin Layer Chromatography}

TLC analysis of $\mathrm{GlA}_{20}, \mathrm{GlA}_{40}$ and GFs showed distinct differences in their $R_{f}$ values. $G A_{20}$ showed only one spot at $R_{f} 0.73$, hence, confirmed the formation of only one product (II). However, in case of $\mathrm{GlA}_{40}$, one major spot was observed at $R_{\mathrm{f}} 0.70$ together with a minor spot at $R_{f} 0.73$. The observation suggested the presence of 
one major compound (III) along with a minor compound (II) in $\mathrm{GlA}_{40}$. The difference in the $\mathrm{R}_{\mathrm{f}}$ values of both products from GFs $\left(R_{\mathrm{f}} 0.77\right)$ indicated the transformation of L-glutamine upon autoclaving.

\section{NMR and mass spectroscopy}

The NMR spectral data $\left({ }^{1} \mathrm{H},{ }^{13} \mathrm{C}\right.$ and $2 \mathrm{D}$ experiments) provided evidence for $\mathrm{GlA}_{20}$ and $\mathrm{GlA}_{40}$ being two structurally different compounds (Figure 1 ).

GlA $_{20}$ was identified as 5-oxo proline (pyroglutamic acid, II) on the basis of comparison of NMR and mass spectral data with reported values. Electrospray ionization mass spectrometry (ESI-MS) of $\mathrm{GlA}_{20}$ showed protonated molecular ion at $\mathrm{m} / z 130[\mathrm{M}+\mathrm{H}]^{+}$which corresponded to the molecular formula $\mathrm{C}_{5} \mathrm{H}_{7} \mathrm{NO}_{3}$.

${ }^{13} \mathrm{C}$ NMR spectrum of $\mathrm{GlA}_{40}$ was dominant with the signals of major product (III) that showed 5 carbon resonances, of which two are observed at $\delta 182.1$ and 180.0 for carbonyls. A downfield shift of these resonances when compared with parent compound (control) indicated presence of a cyclic ring. The other 3 carbons resonated at $\delta 58.2,29.9$ and 25.5. Considerable shifts in these resonances in comparison to the respective resonances of control (L-glutamine) provided further support for the cyclic structure for product III. DEPT 135 experiment revealed the nature of these three resonances as two $\mathrm{CH}_{2}$ at $\delta 29.9$ and 25.5 and one as $\mathrm{CH}$ at $\delta$ 58.2. In ${ }^{1} \mathrm{H}$ NMR spectrum, three multiplets were observed at $\delta 1.93,2.38$ and 4.08, each integrating for two, two and one proton, respectively. The multiplet patterns of these three proton resonances due to mutual scalar couplings indicate that they are connected in series. The coupling pattern was further confirmed by COSY. Electrospray ionization mass spectrometry (ESIMS) of $\mathrm{GlA}_{40}$ showed protonated molecular ion at $\mathrm{m} / \mathrm{z}$

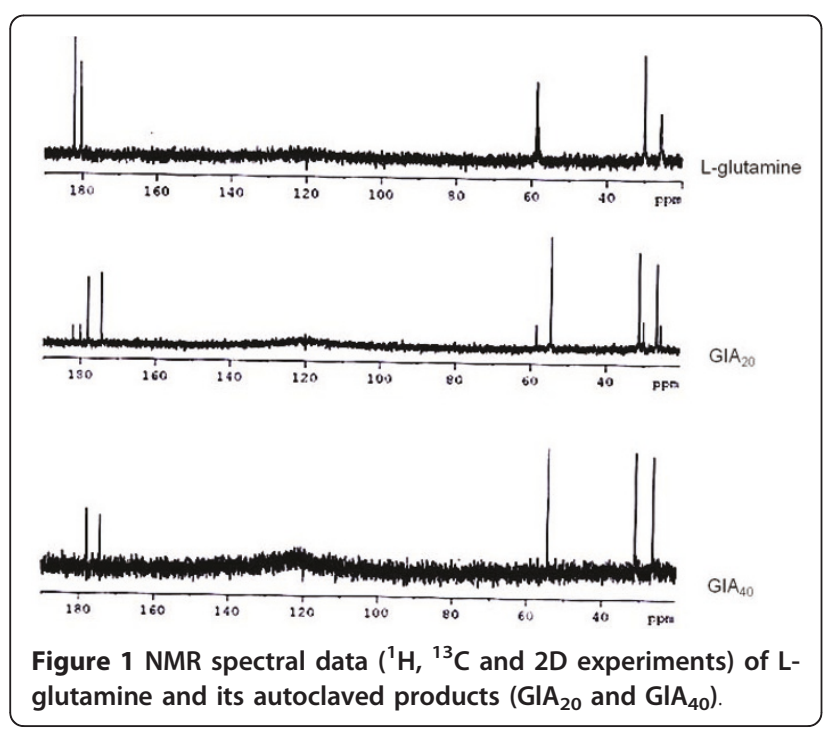

$129[\mathrm{M}+\mathrm{H}]^{+}$for major product (III) which corresponded to the molecular formula $\mathrm{C}_{5} \mathrm{H}_{8} \mathrm{~N}_{2} \mathrm{O}_{2}$. The structural elucidation of compound III finally revealed complete cyclization of glutamine during autoclaving. HMQC and $\mathrm{HMBC}$ study further confirmed the loss of a molecule of water to form compound III i.e. $\alpha$-amino glutarimide or 3-amino-2,6-piperidinedione (Figure 2a and 2b).

The results clearly suggested that the formation of $\alpha$ amino glutarimide (III) was preferred over pyroglutamic acid (II) when L-glutamine was over autoclaved.

$\alpha$-amino glutarimide: ${ }^{1} \mathrm{H}$ NMR $\delta: 1.93(\mathrm{~m}, 2 \mathrm{H}), 2.38$ (m, 2H), 4.08 (q, $1 \mathrm{H}) ;{ }^{13} \mathrm{C}$ NMR $\delta: 182.1,180.0,58.2$, 29.9, 25.5; ESI-MS $m / z: 129[\mathrm{M}+\mathrm{H}]^{+}$.

\section{Agrobacterium growth in response to autoclaved products of L-glutamine}

A. tumefaciens growth was more pronounced at $\mathrm{pH} 7.0$ as compared to acidic $\mathrm{pH}$ (5.2 to 5.9), irrespective of supplements (GFs, $\mathrm{GlA}_{20}$, 5-oxo proline or $\mathrm{GlA}_{40}$ ), and a similar trend was recorded in both YMB and MS (Figure 3). However, growth was remarkably higher in YMB as compared to MS. As compared to control, maximum growth was recorded at $\mathrm{pH} 7.0$ in the presence of $\mathrm{GlA}_{40}$ (i.e, 3.0 and 2.68 fold in YMB and MS, respectively). While growth in the presence of $\mathrm{GlA}_{20}$ was 1.2 and 0.8 fold, that in the presence of 5-oxo proline was about 1.0 and 0.6 fold in YMB and MS, respectively. Growth in the presence of GFs was always lower than

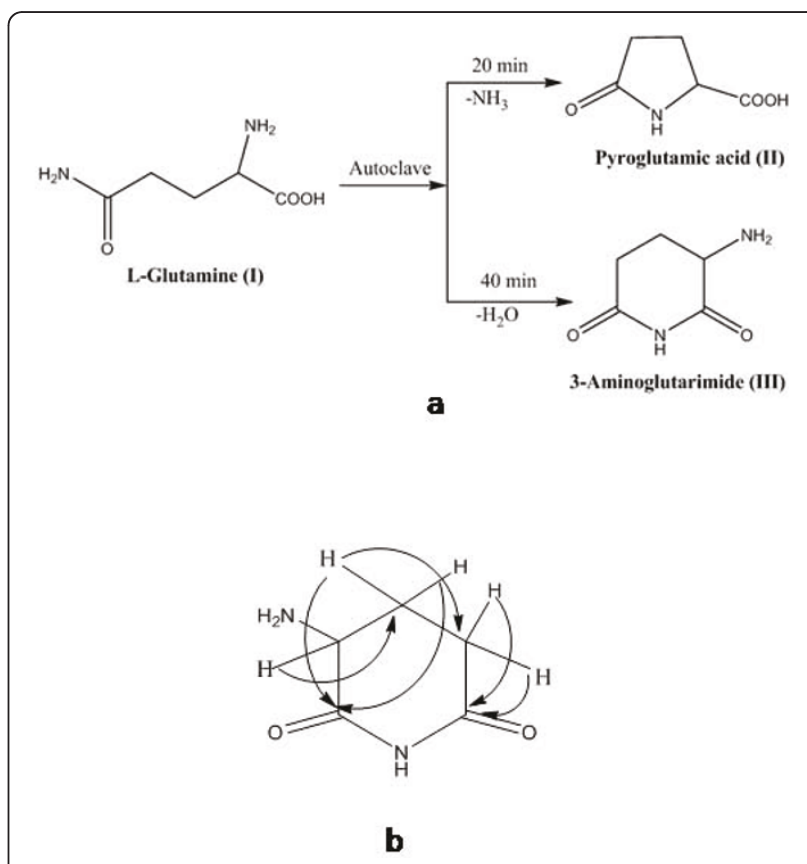

Figure 2 (a) Chemical transformation of L-glutamine into pyroglutamic acid and 3- or $\alpha$-amino glutarimide upon autoclaving at $121^{\circ} \mathrm{C}$ and 15 psi (b) Key HMBC of $\alpha$-amino glutarimide. 


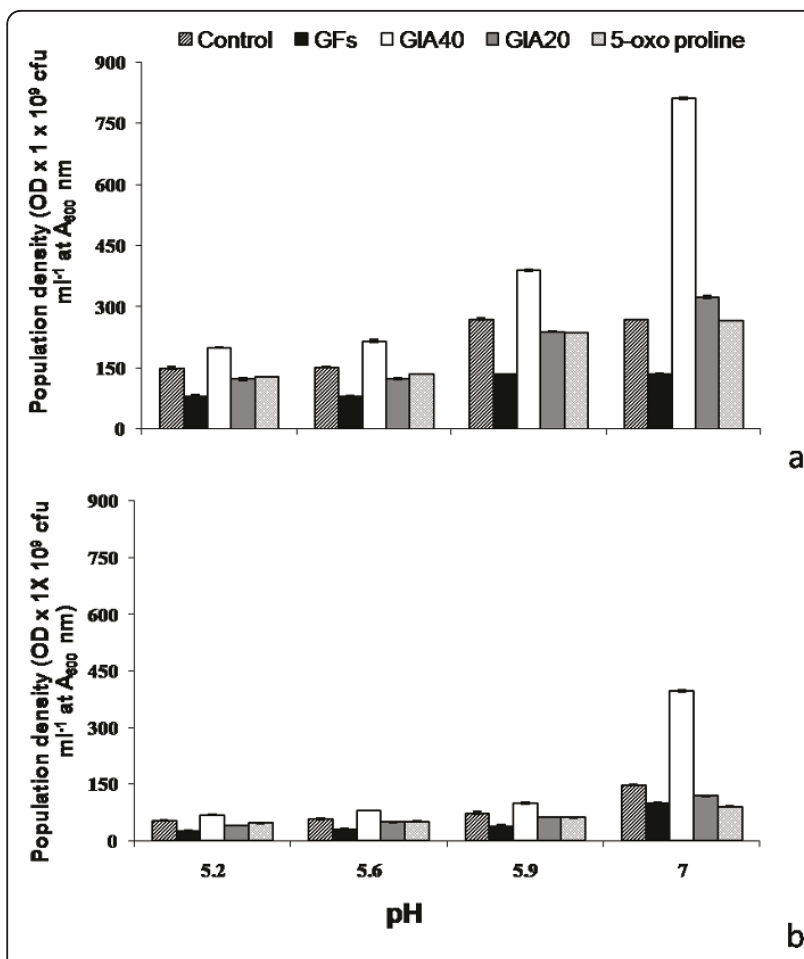

Figure 3 A. tumefaciens growth in (a) YMB and (b) MS as represented by $O D \times 1 \times 10^{9} \mathrm{cfu} \mathrm{ml}^{-1}$ at $A_{600} \mathrm{~nm}$ in response to $2.0 \mathrm{~g} \mathrm{l}^{-1} \mathrm{GFs}, \mathrm{GIA}_{20}, \mathrm{GIA}_{40}$ and control.

control, irrespective of culture media. At acidic $\mathrm{pH}$ of YMB ranging from 5.2 to 5.6, growth was lower than that in the presence of GFs (0.5 to 0.54 fold), $\mathrm{GlA}_{20}$ ( 0.81 to 0.89 fold) and 5 -oxo proline $(0.88$ fold). However, about 1.4 fold growth was recorded in the presence of $\mathrm{GlA}_{40}$ (Figures 3 and 4). In case of MS, a trend similar to that in YMB was observed. While growth was lower by 0.5 fold in the presence of GFs, it ranged between 0.75 to 0.88 fold in the presence of $\mathrm{GlA}_{20}$ and 5 -oxo proline. However, growth in presence of $\mathrm{GlA}_{40}$ was 1.3 to 1.4 fold.

\section{$\beta$-galactosidase activity as a measure of Agrobacterium virulence (vir) gene induction}

Considerably high $\beta$-galactosidase activity was recorded in the presence of AS, a known vir gene inducer. However, the activity of control (no additions) was lower than that in the presence of AS (Table 1). While the activities were 132.7 and 132.0 Miller units in the presence of GFs and $\mathrm{GlA}_{20}$, respectively, suppression (130.9 Miller units) was observed in the presence of $\mathrm{GlA}_{40}$.

\section{Agrobacterium infection of resistant host plants by autoclaved products of L-glutamine}

A. tumefaciens growth on leaf explants varied with plant species when transformed with different cell densities

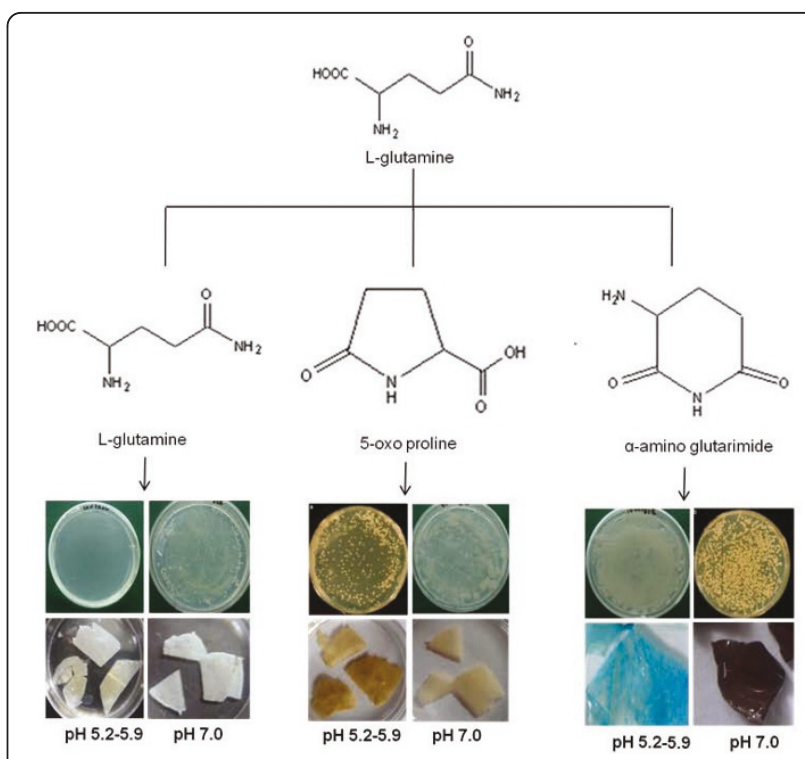

Figure 4 Effect of $\mathrm{pH}$ (5.2-5.9 and 7.0) on A. tumefaciens growth and GUS expression of explants transformed in presence of $\mathrm{GFs}, \mathrm{GlA}_{20}$ and $\mathrm{GlA}_{40}$.

and co-cultivated on MS supplemented with $\mathrm{GlA}_{40}$. No growth was observed on any of the explants when transformed with $1 \times 10^{7} \mathrm{cfu} \mathrm{ml}^{-1}$ of A. tumefaciens followed by co-cultivation on MS containing either of GFs, $\mathrm{GlA}_{20}$ or 5-oxo proline. Slight A. tumefaciens growth was however, recorded on explants of bamboo, maize and apple rootstock transformed using a cell density of $1 \times 10^{7} \mathrm{cfu}$ $\mathrm{ml}^{-1}$ followed by co-cultivation in the presence of $\mathrm{GlA}_{40}$. No explant, except tobacco showed A. tumefaciens growth when co-cultivated on control medium after transformation using cell densities up to $1 \times 10^{8} \mathrm{cfu} \mathrm{ml}^{-1}$. However, explants of apple rootstock, bamboo, maize, and rice showed slight growth on control medium at all tested cell densities beyond $1 \times 10^{8} \mathrm{cfu} \mathrm{m}^{-1}$.

Growth increased with further increase in cell density i. e., lowest at $1 \times 10^{8} \mathrm{cfu} \mathrm{ml}^{-1}$ and highest at $1 \times 10^{10} \mathrm{cfu}$ $\mathrm{ml}^{-1}$ in case of Indian may apple, aloe, lavender, wild rose, apple rootstock, bamboo, grass, maize and rice; and also in the leaf explants of fern and Aurocaria when co-cultivated on MS containing $\mathrm{GlA}_{40}$ (Figure 5). Even in case of control i.e., in the absence of supplements, $A$. tumefaciens growth

Table 1 vir gene induction by L-glutamine (GFs) and its autoclaved products (GIA 20 and $\mathrm{GIA}_{40}$ )

\begin{tabular}{cl}
\hline Compound tested & $\boldsymbol{\beta}$-galactosidase activity ( Miller units) \\
\hline Control & $58.9 \pm 0.6$ \\
\hline $\mathrm{AS}(200 \mu \mathrm{M})$ & $148.0 \pm 1.1$ \\
\hline $\mathrm{GFs}$ & $132.7 \pm 0.7$ \\
\hline $\mathrm{GIA}_{20}$ & $132.0 \pm 0.6$ \\
\hline $\mathrm{GIA}_{40}$ & $130.9 \pm 0.9$ \\
\hline
\end{tabular}




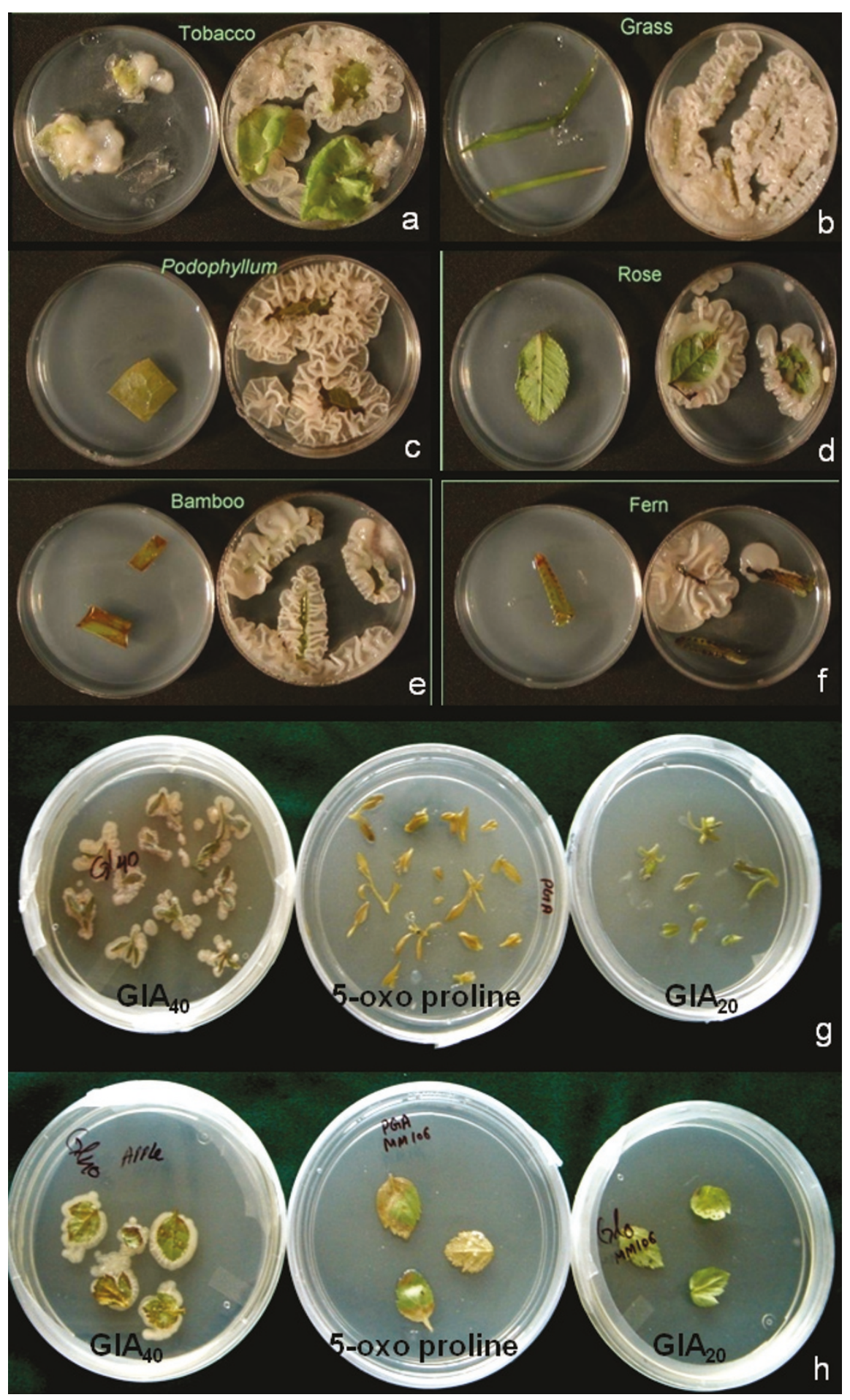

Figure 5 Agrobacterium growth on leaf explantsof; (a) tobacco, (b) grass, (c) Indian may apple, (d) rose, (e) bamboo and (f) fern (transformed using $1 \times 10^{9} \mathrm{cfu} \mathrm{ml}^{-1}$ followed by co-cultivation on MS containing $\mathrm{GlA}_{40}$ at $\mathrm{pH}$ 5.6); (g-h) growth in response to $\mathrm{Gl} \mathrm{A}_{40}$, 5-oxo proline and $\mathrm{GlA} \mathrm{A}_{20}$ (g: lavender, h: apple rootstock MM106). 
was observed on apple rootstock and rice when they were transformed using either of $1 \times 10^{9}$ or $1 \times 10^{10} \mathrm{cfu} \mathrm{ml}^{-1}$. However, A. tumefaciens failed to grow on any of the explants when either $\mathrm{GlA}_{20}$ or 5-oxo proline was present in the co-cultivation medium, irrespective of cell densities, (Sigma, USA).

When $\mathrm{pH}$ of the co-cultivation medium was considered, depending upon the plant species, slight to profuse growth was recorded on or around the explants in the acidic $\mathrm{pH}$ range only. In contrast, no $A$. tumefaciens growth was recorded on or around the explant surface at $\mathrm{pH}$ 7.0, irrespective of supplements.

\section{GUS expression}

GUS expression varied with $A$. tumefaciens density, plant species or presence or absence of $\mathrm{GlA}_{40}$ (Table 2). Irrespective of the presence or absence of $\mathrm{GlA}_{40}$ in the co-cultivation medium, tobacco showed GUS expression at all cell densities ranging from $1 \times 10^{7}$ and $1 \times 10^{9} \mathrm{cfu}$ $\mathrm{ml}^{-1}$. On the other hand, the presence of $\mathrm{GlA}_{20}$ or 5-oxo proline failed to induce GUS expression in all the studied plant species including tobacco.

GUS expression improved with increase in A. tumefaciens cell densities from $1 \times 10^{7}$ to $1 \times 10^{9} \mathrm{cfu} \mathrm{m}^{-1}$ in the presence of $\mathrm{GlA}_{40}$ in case of apple rootstock, bamboo and maize; and from $1 \times 10^{8}$ to $1 \times 10^{9} \mathrm{cfu} \mathrm{ml}^{-1}$ in Indian may apple, aloe, lavender, grass and rice. However, the best response in terms of strong GUS expression spread over a larger area was recorded, only when $1 \times 10^{9} \mathrm{cfu} \mathrm{ml}^{-1}$ of $A$. tumefaciens was used, irrespective of plant species (Figure 6). Increase in cell density beyond $1 \times 10^{9} \mathrm{cfu} \mathrm{ml}^{-1}$ had no effect on GUS expression (or in other words transformation) in case of aloe, grass, maize, rice, aurocaria and fern. On the other hand, with time, the explants turned necrotic due to A. tumefaciens overgrowth at $1 \times 10^{10} \mathrm{cfu} \mathrm{ml}^{-1}$ in case of tobacco, Indian may apple, lavender, wild rose and apple rootstock.

Table 2 GUS expression after 2 days of co-cultivation in leaf explants transformed using different A. tumefaciens population densities

\begin{tabular}{|c|c|c|c|c|c|c|c|c|c|c|c|c|c|c|c|c|c|}
\hline \multirow{3}{*}{$\begin{array}{l}\text { S. } \\
\text { No. }\end{array}$} & \multirow{3}{*}{ Plant species } & \multicolumn{16}{|c|}{ A. tumefaciens population density $\left(\mathrm{cfu} \mathrm{ml}^{-1}\right.$ ) versus GUS expression in different plant species } \\
\hline & & \multicolumn{4}{|c|}{$1 \times 10^{7}$} & \multicolumn{4}{|c|}{$1 \times 10^{8}$} & \multicolumn{4}{|c|}{$1 \times 10^{9}$} & \multicolumn{4}{|c|}{$1 \times 10^{10}$} \\
\hline & & Cont* & $\mathrm{GIA}_{20}$ & $\begin{array}{c}\text { 5-oxo } \\
\text { proline }\end{array}$ & $\mathrm{GIA}_{40}$ & Cont & $\mathrm{GIA}_{20}$ & $\begin{array}{l}\text { 5-oxo } \\
\text { proline }\end{array}$ & $\mathrm{GIA}_{40}$ & Cont & $\mathrm{GIA}_{20}$ & $\begin{array}{l}\text { 5-oxo } \\
\text { proline }\end{array}$ & $\mathrm{GIA}_{40}$ & Cont & $\mathrm{GIA}_{20}$ & $\begin{array}{l}\text { 5-oxo } \\
\text { proline }\end{array}$ & $\mathrm{GIA}_{40}$ \\
\hline 1. & $\begin{array}{l}\text { Nicotiana } \\
\text { tabacum } \\
\text { (tobacco) }\end{array}$ & ++ & - & - & ++ & ++ & - & - & ++ & $\begin{array}{c}+++ \\
++\end{array}$ & - & - & $\begin{array}{c}+++ \\
++\end{array}$ & - & - & - & - \\
\hline 2. & $\begin{array}{l}\text { Podophyllum } \\
\text { hexandrum } \\
\text { (Indian may } \\
\text { apple) }\end{array}$ & - & - & - & - & - & - & - & + & - & - & - & $\begin{array}{c}+++ \\
+\end{array}$ & - & - & - & - \\
\hline 3. & Aloe vera (aloe) & - & - & - & - & - & - & - & + & - & - & - & ++ & - & - & - & ++ \\
\hline 4. & $\begin{array}{l}\text { Lavendula } \\
\text { officinalis } \\
\text { (lavender) }\end{array}$ & - & - & - & - & - & - & - & + & - & - & - & +++ & - & - & - & - \\
\hline 5. & $\begin{array}{l}\text { Rosa sp. } \\
\text { (Wild rose) }\end{array}$ & - & - & - & - & - & - & - & - & - & - & - & +++ & - & - & - & - \\
\hline 6. & $\begin{array}{l}\text { Malus domestica } \\
\text { (apple } \\
\text { rootstock) }\end{array}$ & - & - & - & + & - & - & - & ++ & - & - & - & $\begin{array}{c}++ \\
++\end{array}$ & - & - & - & - \\
\hline 7. & $\begin{array}{l}\text { Dendrocalamus } \\
\text { asper (bamboo) }\end{array}$ & - & - & - & ++ & - & - & - & +++ & - & - & - & $\begin{array}{c}+++ \\
++\end{array}$ & - & - & - & $\begin{array}{c}++ \\
+\end{array}$ \\
\hline 8. & $\begin{array}{l}\text { Cynodon } \\
\text { dactylon (grass) }\end{array}$ & - & - & - & - & - & - & - & + & - & - & - & $\begin{array}{c}+++ \\
+\end{array}$ & - & - & - & $\begin{array}{c}++ \\
+\end{array}$ \\
\hline 9. & $\begin{array}{l}\text { Zea mays } \\
\text { (maize) }\end{array}$ & - & - & - & + & - & - & - & ++ & - & - & - & +++ & - & - & - & +++ \\
\hline 10. & $\begin{array}{l}\text { Oryza sativa } \\
\text { (rice) }\end{array}$ & - & - & - & - & - & - & - & +++ & +++ & - & - & $\begin{array}{c}++ \\
+\end{array}$ & +++ & - & - & $\begin{array}{c}++ \\
+\end{array}$ \\
\hline 11. & $\begin{array}{l}\text { Aurocaria } \\
\text { (gymnosperm) }\end{array}$ & - & - & - & - & - & - & - & - & - & - & - & $\begin{array}{c}++ \\
+ \\
\end{array}$ & - & - & - & $\begin{array}{c}++ \\
+ \\
\end{array}$ \\
\hline 12. & $\begin{array}{l}\text { Dryopteris (fern, } \\
\text { pteridophyte) }\end{array}$ & - & - & - & - & - & - & - & - & - & - & - & $\begin{array}{c}+++ \\
+\end{array}$ & - & - & - & $\begin{array}{c}++ \\
+\end{array}$ \\
\hline
\end{tabular}

where Cont* $=$ control; $+=$ one to five tiny blue spots; $++=$ one to two large blue spots; $+++=$ small or faint blue patches; $++++=$ large blue patch covering almost quarter of the leaf surface; and $+++++=$ entire leaf showed distinct blue color. 


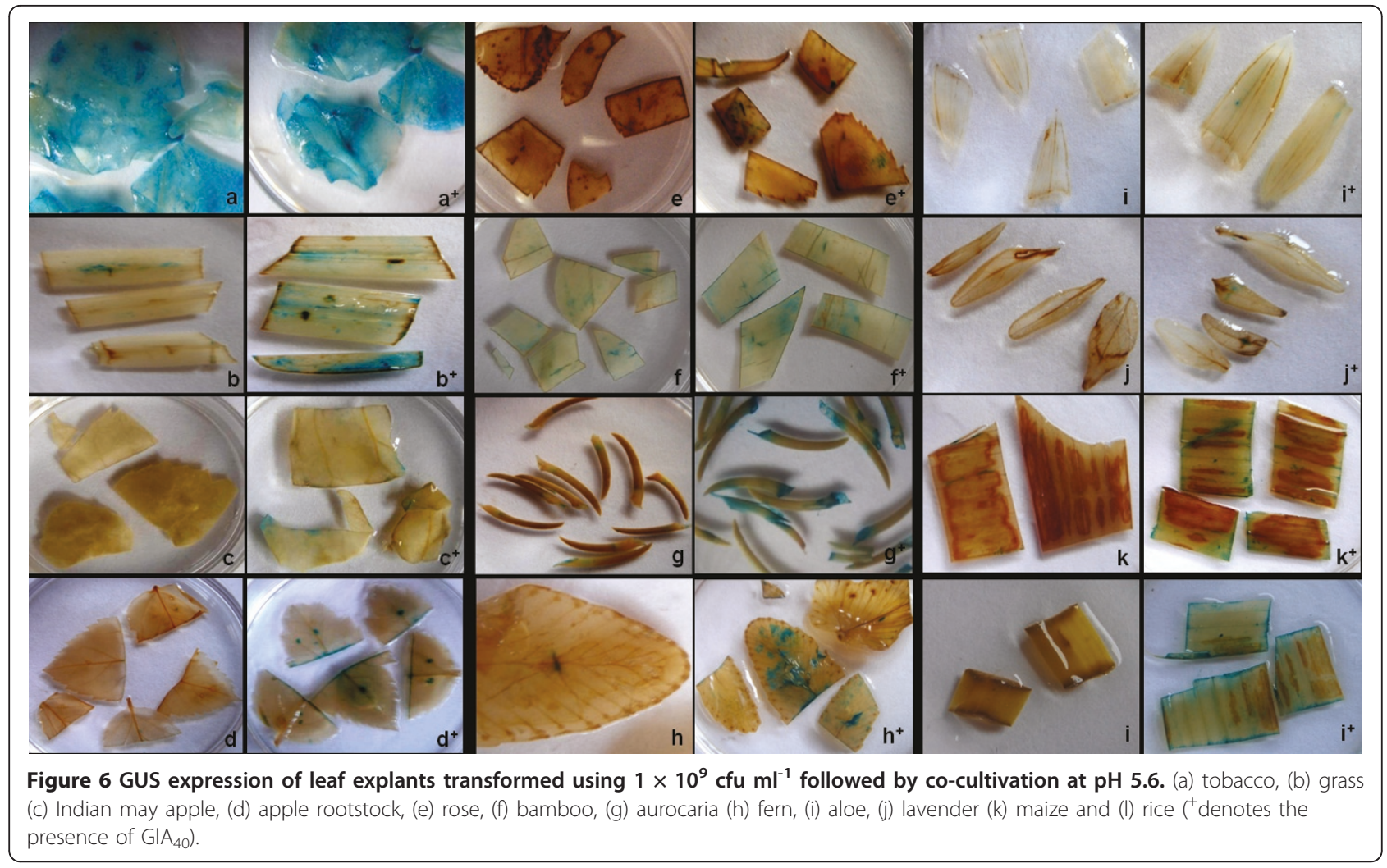

The leaf explants of all the studied plant species showed GUS expression only in the acidic $\mathrm{pH}$ range when co-cultivated on MSC containing $\mathrm{GlA}_{40}$. However, the $\mathrm{pH}$ optima and the intensity of expression varied with the plant species tested (Table 3). While the leaf explants of tobacco, lavender, apple rootstock, bamboo, maize and rice showed GUS expression at all $\mathrm{pH}$ in the acidic range (i.e., 5.2, 5.6 and 5.9), those of Indian may apple, wild rose and grass showed GUS expression at $\mathrm{pH} 5.6$ and 5.9 only. On the other hand, the explants of aloe and fern tested positive when co-cultivated at $\mathrm{pH}$ 5.2 and 5.6, whereas, that in aurocaria was best observed at $\mathrm{pH} 5.6$ only.

In case of media containing $100 \mu \mathrm{M}$ AS, but free of all glutamine supplements, longer co-cultivation time was required for the explants of wild rose, apple rootstock, bamboo, grass, maize, rice and fern (Table 3). The only exception was tobacco where $<1$ day of co-cultivation was sufficient for strong GUS expression. On the other hand, no GUS expression was observed in explants of any of the plant species co-cultivated at pH 7.0 (Table 3; Figure 4).

\section{PCR confirmation of genetic transformation}

PCR amplification products of about $490 \mathrm{bp}$ corresponding to gus gene were observed in the leaf calli of aloe, lavender, tobacco, rose, grass, fern and apple rootstock and maize provided $\mathrm{GlA}_{40}$ was present in the co-cultivation medium (Figure 7a, b, c and 7d). However, amplification was not detected in the calli derived from explants co-cultivated on either control or on media containing GFs, $\mathrm{GlA}_{20}$ or AS.

\section{Southern hybridization}

Genomic DNA of calli derived from aloe, wild rose, maize, fern, lavender and grass leaves transformed using A. tumefaciens density of $1 \times 10^{9} \mathrm{cfu} \mathrm{ml}^{-1}$ and co-cultivated in the presence of $\mathrm{GlA}_{40}$ tested positive in Southern hybridization and distinct purple-blue signals were detected (Figure 8). However, no hybridization signals were observed in case of leaf calli obtained from explants co-cultivated in the presence of AS but in absence of $\mathrm{GlA}_{40}$ (Figure 8a). Hybridization signals were also not detected in the untransformed leaf calli of the studied plant species (not shown). Only tobacco and apple rootstock MM106 showed the hybridization signals both in the presence or absence of $\mathrm{GlA}_{40}$ in the co-cultivation medium (not shown). A distinct single band (>3 kb) was observed in case of aloe (Figure 8b, lanes 1 and 2). While a distinctly sharp band of $>3 \mathrm{~kb}$ was observed along with $>1.5 \mathrm{~kb}$ and $700 \mathrm{bp}$ bands in wild rose (Figure 8b, lane 3), four bands above $3 \mathrm{~kb}$ and two bands of about $1.8 \mathrm{~kb}$ and $700 \mathrm{bp}$ were observed in maize (Figure 8b, lane 4). No signal was observed in case of fern (Figure 8b, lane 5) 
Table 3 GUS expression in response to different $\mathrm{pH}$ during co-cultivation on MSC containing $\mathrm{GIA}_{40}$ after transformation of leaf explants of different plant species using $1 \times 10^{9} \mathrm{cfu} \mathrm{ml}^{-1} A$. tumefaciens

\begin{tabular}{|c|c|c|c|c|}
\hline \multirow[t]{2}{*}{ S. No. } & \multirow[t]{2}{*}{ Plant Species } & \multirow[t]{2}{*}{$\mathrm{pH}$} & \multicolumn{2}{|c|}{ GUS Expression } \\
\hline & & & $(+) \mathrm{GlA}_{40}$ & $(-) \mathrm{GIA}_{40}$ \\
\hline \multirow[t]{4}{*}{1.} & Nicotiana tabacum (tobacco) & 5.2 & $+++++(<1$ day $)$ & $+++++(<1$ day $)$ \\
\hline & & 5.6 & $+++++(<1$ day $)$ & $+++++(<1$ day $)$ \\
\hline & & 5.9 & $+++++(<1$ day $)$ & $+++++(<1$ day $)$ \\
\hline & & 7.0 & - & - \\
\hline \multirow[t]{4}{*}{2.} & Podophyllum hexandrum (Indian may apple) & 5.2 & - & - \\
\hline & & 5.6 & $++++(2$ days $)$ & - \\
\hline & & 5.9 & +++ (2 days $)$ & - \\
\hline & & 7.0 & - & - \\
\hline \multirow[t]{4}{*}{3.} & Aloe vera (aloe) & 5.2 & $+++(1$ day $)$ & - \\
\hline & & 5.6 & $+++(1$ day $)$ & - \\
\hline & & 5.9 & - & - \\
\hline & & 7.0 & - & - \\
\hline \multirow[t]{4}{*}{4.} & Lavendula officinalis (lavender) & 5.2 & $+++(1$ day $)$ & - \\
\hline & & 5.6 & $++++(1$ day $)$ & - \\
\hline & & 5.9 & $+++(1$ day $)$ & - \\
\hline & & 7.0 & - & - \\
\hline \multirow[t]{4}{*}{5.} & Rosa sp. (Wild rose) & 5.2 & - & - \\
\hline & & 5.6 & $+++(1$ day $)$ & $+(4$ days $)$ \\
\hline & & 5.9 & $+++(1$ day $)$ & $+(5$ days $)$ \\
\hline & & 7.0 & - & - \\
\hline \multirow[t]{4}{*}{6.} & Malus domestica (apple rootstock) & 5.2 & $++++(2$ days $)$ & $+(3$ days $)$ \\
\hline & & 5.6 & $++++(2$ days $)$ & + (3 days) \\
\hline & & 5.9 & $++++(2$ days $)$ & $+(3$ days $)$ \\
\hline & & 7.0 & - & - \\
\hline \multirow[t]{4}{*}{7.} & Dendrocalamus asper (bamboo) & 5.2 & $+(2$ days $)$ & $+(6$ days $)$ \\
\hline & & 5.6 & $+++(1$ day $)$ & $+(3$ days $)$ \\
\hline & & 5.9 & $++(1$ day $)$ & + (4 days) \\
\hline & & 7.0 & - & - \\
\hline \multirow[t]{4}{*}{8.} & $\begin{array}{c}\text { Cynodon dactylon } \\
\text { (grass) }\end{array}$ & 5.2 & - & - \\
\hline & & 5.6 & $++(1$ day $)$ & $+(5$ days $)$ \\
\hline & & 5.9 & $++(1$ day $)$ & + (3 days) \\
\hline & & 7.0 & - & - \\
\hline \multirow[t]{4}{*}{9.} & Zea mays (maize) & 5.2 & $+++(1$ day $)$ & + (3 days) \\
\hline & & 5.6 & $+++(1$ day $)$ & $+(3$ days $)$ \\
\hline & & 5.9 & ++++ (1 day) & $+(5$ days $)$ \\
\hline & & 7.0 & - & - \\
\hline \multirow[t]{4}{*}{10.} & Oryza sativa (rice) & 5.2 & $++(1$ day $)$ & $+(4$ days $)$ \\
\hline & & 5.6 & $+++(1$ day $)$ & $+(2$ days $)$ \\
\hline & & 5.9 & $+++(1$ day $)$ & $+(2$ days $)$ \\
\hline & & 7.0 & - & - \\
\hline \multirow[t]{4}{*}{11.} & Aurocaria (gymnosperm) & 5.2 & - & - \\
\hline & & 5.6 & $++++(3$ days $)$ & - \\
\hline & & 5.9 & - & - \\
\hline & & 7.0 & - & - \\
\hline
\end{tabular}


Table 3 GUS expression in response to different pH during co-cultivation on MSC containing GIA 40 after transforma-

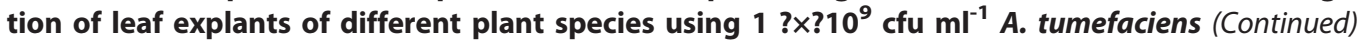

\begin{tabular}{|c|c|c|c|c|}
\hline \multirow[t]{4}{*}{12.} & Dryopteris (fern, pteridophyte) & 5.2 & ++ (1 day) & $+(7$ days $)$ \\
\hline & & 5.6 & +++ (1 day) & + (3 days) \\
\hline & & 5.9 & - & - \\
\hline & & 7.0 & - & - \\
\hline
\end{tabular}

where $+=$ one to five tiny blue spots; $++=$ one to two large blue spots; $+++=$ small or faint blue patches; $++++=$ large blue patch covering almost quarter of the leaf surface; $+++++=$ entire leaf showed distinct blue color and - = no GUS expression (Values in parenthesis represent the duration of co-cultivation)

whereas, two sharp bands of about $1.8 \mathrm{~kb}$ and $700 \mathrm{bp}$ were observed in case of lavender (Figure 8, lanes 6 and 7). Three distinct bands (400 bp, $900 \mathrm{bp}$ and $2.8 \mathrm{~kb}$ ) were observed in case of grass (Figure 8, lane 8).

\section{Discussion}

L-glutamine is a highly thermolabile and non-volatile biomolecule that is chemically modified into different compounds at high temperatures. When present in aqueous solution at $\mathrm{pH}$ values that are not extreme, L-glutamine is transformed in two step reactions, first into glutamic acid and then into pyroglutamic acid or 5-pyrrolidone-2-carboxylic acid or 5-oxo proline and ammonia [23]. Besides 5-pyrrolidone-2-carboxylic acid [24], Lglutamine undergoes pyrolysis at temperatures as high as $300^{\circ} \mathrm{C}$ leading to the formation of nitrogen containing heterocycles [25]. The additional single methylene group in the side chain allows the free form of glutamine to cyclize and de-amidate spontaneously into pyrrolidone carboxylic acid, a five-membered ring structure found at the $\mathrm{N}$-terminus of many immunoglobulin polypeptides [26]. In the present study also, L-glutamine underwent cyclization to form 5 -oxoproline and $\alpha$-amino glutarimide. However, this occurred when L-glutamine was autoclaved at $121^{\circ} \mathrm{C}$ and $15 \mathrm{psi}$ for 20 and $40 \mathrm{~min}$, respectively (Figure $2 \mathrm{a}$ and $2 \mathrm{~b}$ ). Further chemical investigations using TLC and different spectroscopic methods revealed that irrespective of the duration of autoclaving, both the compounds could be detected in the same sample. However, the amount of $\alpha$-amino glutarimide was more (92-95\%) when the aqueous solution of L-glutamine was autoclaved for $40 \mathrm{~min}$. This indicated the possibility of easy synthesis of $\alpha$-amino glutarimide simply by autoclaving aqueous solutions of L-glutamine for $40 \mathrm{~min}$. It would be pertinent to mention that in general, the synthesis of the glutarimide ring requires a minimum of 2-3 step reactions [8,27].

Glutarimides are extremely valuable biomolecules that act as a carrier or vector for transporting biologically active functional groups through cell membranes. The structural features and physiochemical properties of the glutarimide moiety is remarkably similar to the uracil derivatives. Therefore, it interacts with specific receptors involved in transport of uracil and thymine nucleosides across biological membranes [28,29]. Being a constituent of a large number of other important compounds, the glutarimide moeity possesses a broad spectrum of pharmacological and anticancer properties [2,30,31]. Particularly, 2,6-piperidinedione, a glutarimide with an intact imide group (OC-NH-CO) substituted at $\alpha$ and $\beta$

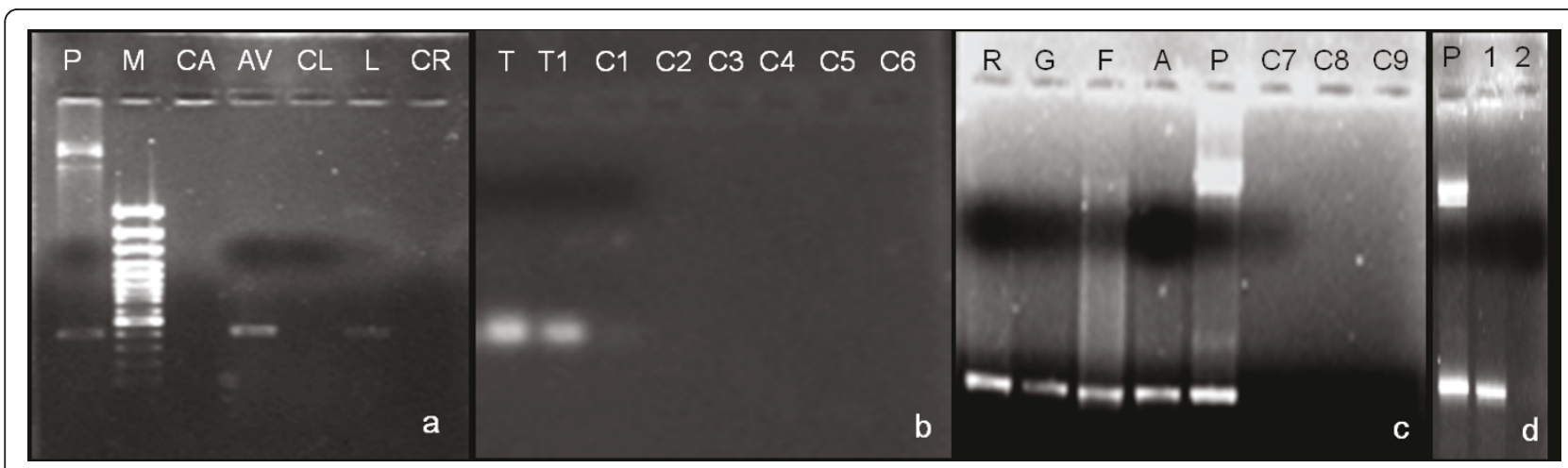

Figure 7 PCR of genomic DNA from leaf callus showing amplification of $\mathbf{4 9 0}$ bp gus gene. (a) Lane P: plasmid, Lane M: 0'GeneRulerTM 100 bp plus DNA ladder (Fermentas, Life Sciences), Lanes CA-AV: transformed aloe (CA: in absence of GIA 40 and AV: in presence of GIA $\left.A_{40}\right)$, Lanes CL and $L$ : transformed lavender (CL: in absence of $G \mid A_{40}$, and $L$ : in presence of $\left.G \mid A_{40}\right)$, Lane $C R$ : transformants in absence of $G \mid A_{40}(C R$ : wild rose); (b) Lane T-T1: transformed tobacco ( $T$ : in absence of $G \mid A_{40}$, $T 1$ : in presence of $G \mid A_{40}$ ), Lanes $C 1$ to C6: untransformed controls (1: aloe, 2: lavender, 3: wild rose, 4: grass, 5: fern, 6: apple rootstock); (c) Lanes R, G, F, A: transformed calli in presence of GlA 40 (R: wild rose, G: grass, F: fern, A: apple rootstock) P: plasmid and Lanes C7-C9: transformants in absence of GlA 40 (7: apple rootstock, 8: fern, 9: grass) and (d) Lane P: Plasmid DNA, Lane 1: maize transformed in presence of $\mathrm{GIA}_{40}$; Lane 2: transformant in absence of $\mathrm{GI} \mathrm{A}_{40}$. 


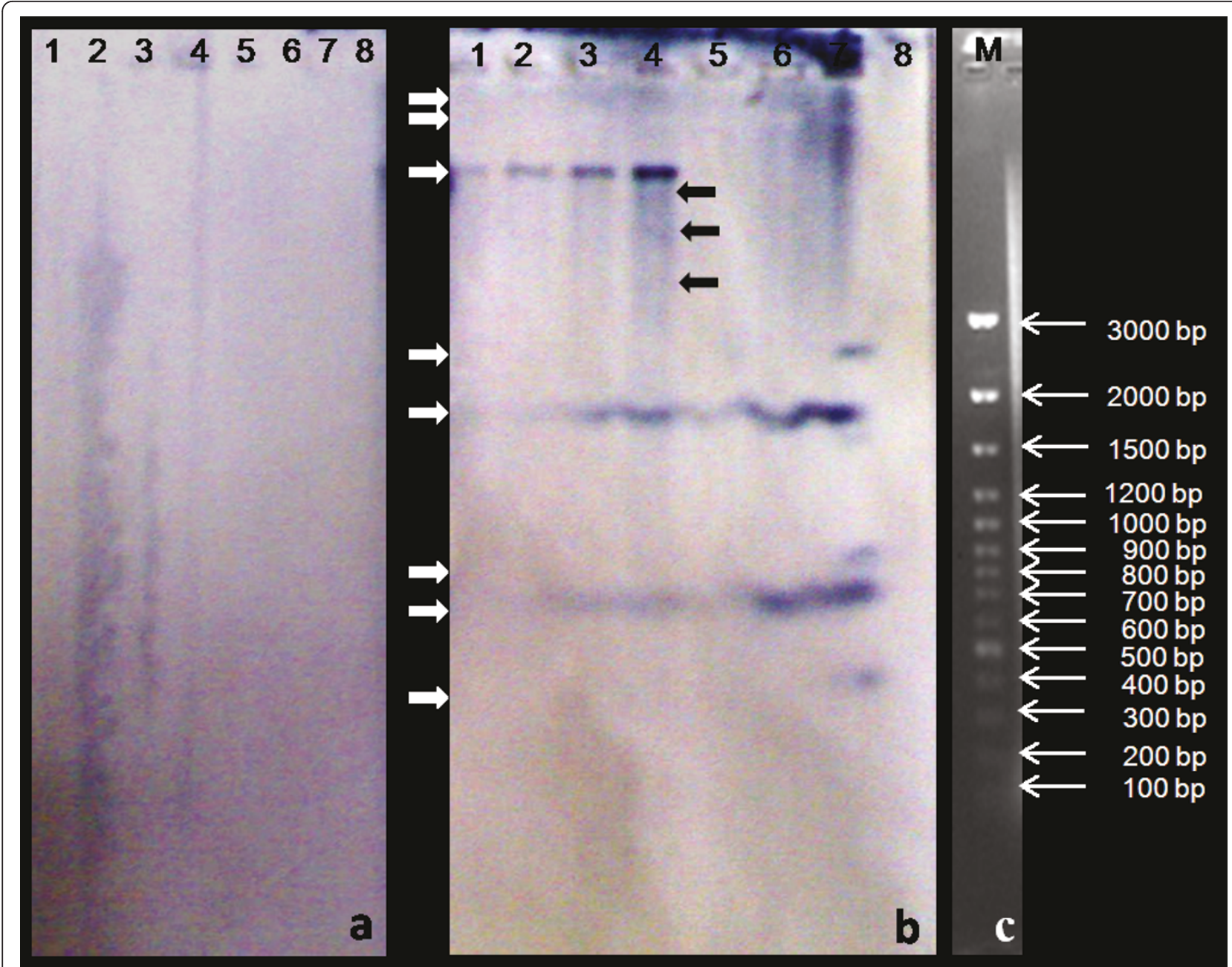

Figure 8 Southern blot of genomic DNA from leaf callus hybridized with Biotin labeled gus gene probe. (a) Control Lanes 1-5: transformants in absence of $\mathrm{GIA}_{40}$ but presence of AS (1 and 2: aloe, 3: wild rose, 4: maize, 5: fern, 6: lavender, 7: grass (b) transformants in presence of $\mathrm{GIA}_{40}$ (Lane 1 and 2: aloe, 3: wild rose, 4: maize, 5: fern, 6 and 7: lavender, 8: grass); (c) M: 0'GeneRuler ${ }^{\mathrm{TM}} 100$ bp plus DNA ladder (Fermentas, Life Sciences).

position in the ring acts as a powerful inhibitor of human rhinovirus $3 \mathrm{C}$ protease [32]. However, in the present study $\alpha$-amino glutarimide was found to have a new function of facilitating Agrobacterium infection of different susceptible and resistant plant species that ranged from host to non-hosts (Tables 2 and 3; Figures 3, 4, 5, 6, 7 and 8). The present study also found that neither 5-oxoproline nor 3-amino glutarmide are inducers of the vir regulon (Table 1). Rather, the compound promoted A. tumefaciens growth resulting in an increase in population density. However, increase in population density beyond $1 \times 10^{9} \mathrm{cfu} \mathrm{ml}^{-1}$ was found to have a detrimental effect on transformation efficiency (Table 2). This led us to hypothesize that $\alpha$-amino glutarimide formed due to autoclaving of L-glutamine was probably responsible for the xenobiotic quenching of the toxic wound exudates from resistant explants as has been indicated in tea [33]. This appears to be so because most of the plant species that were tested in the present study, leached exudates that not only killed the studied explants (data not shown) but also retarded A. tumefaciens growth as has been shown in tea in our earlier study [33]. These bactericidal leachates probably killed or prevented the chemotaxis of an optimal A. tumefaciens population density required for explant infection. Not surprisingly, the possibility of a strong negative influence by the toxic polyphenolic exudates on the chemotactic movement of Agrobacteria towards the explant has been considered [34]. On the other hand, when the bactericidal-explant-exudates were possibly quenched by $\alpha$-amino glutarimide, the requisite population density of A. tumefaciens which would otherwise have been repelled or killed, were now allowed to move towards the explants for infection (Figure 9a and 9b). 


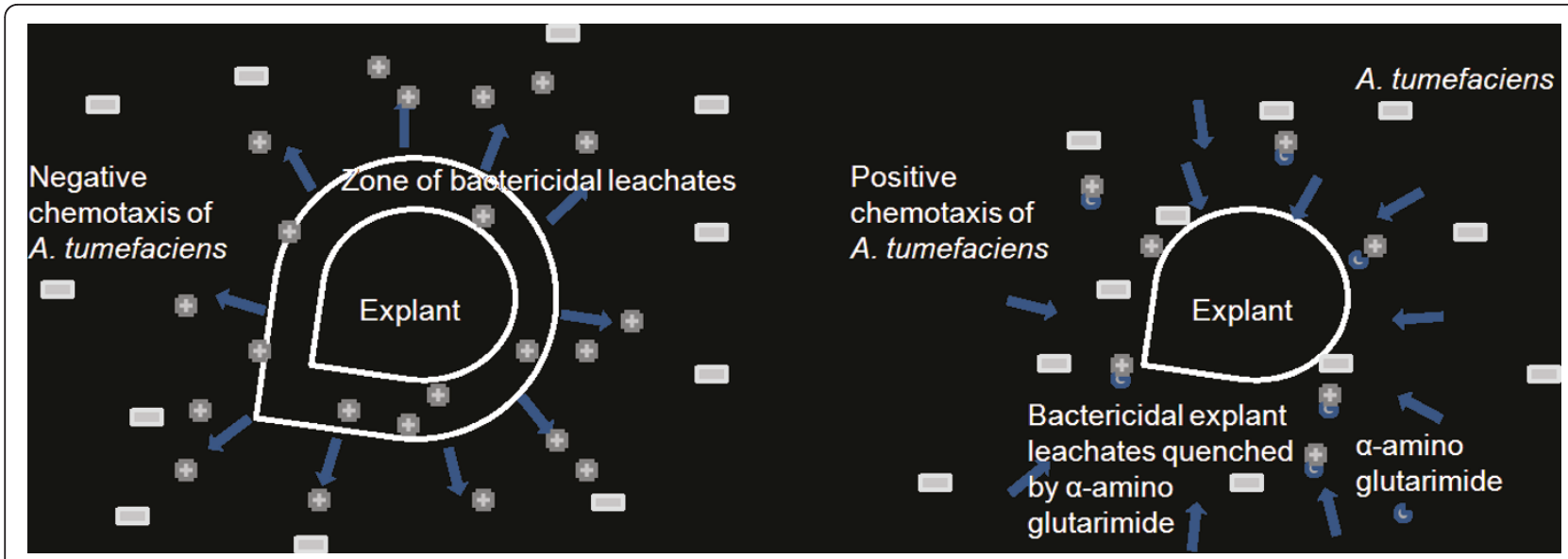

Figure 9 A hypothetical diagram showing how $\alpha$-amino glutarimide facilitates $A$. tumefaciens infection of non-host explants that exude bactericidal/bacteriostatic leachates.

However, the activity of $\mathrm{GlA}_{40}$ was found to be $\mathrm{pH}$ dependant. While Agrobacterium growth was enhanced at $\mathrm{pH}$ 7.0, infectivity of explants of many of the studied plant species was mostly enhanced at $\mathrm{pH} 5.6$ and some at pH 5.2 and 5.9, but never at pH 7.0 (Table 3 and Figure 4). This indicated the necessity of manipulation of $\mathrm{pH}$ of the media containing this compound for its appropriate utilization. Actually, vir gene induction and consequent Agrobacterium infection of plants is best facilitated at acidic $\mathrm{pH}$ [35]. However, the $\mathrm{pH}$ optima are known to vary with plant species for Agrobacterium virulence and gene transfer [36-38]. Designing adequate artificial environment and manipulation of wound responses of plant tissues has facilitated successful genetic transformation of many plant species by favoring plant- $A$. tumefaciens interactions.

\section{Conclusions}

5-oxo proline and $\alpha$-amino glutarimide were synthesized from L-glutamine upon autoclaving at $121^{\circ} \mathrm{C}$ and $15 \mathrm{psi}$ for 20 or $40 \mathrm{~min}$. Although the compound did not have any vir gene inducing property, $\alpha$-amino glutarimide facilitated Agrobacterium infection of a number of resistant to susceptible plants successfully.

\section{Acknowledgements}

The authors gratefully acknowledge Dr. S. D. Ravindranath, without whose innovative ideas, the conceptualization and successful completion of this work would not be possible. The kind help of Dr A. P. Gupta and Dr. V. K. Kaul in structural elucidation of $\alpha$-amino glutarimide is acknowledged. Mr. Pabitra Gain is acknowledged for his photography. The financial assistance in the form of project grants as well as Senior Research Fellowships from the Council of Scientific and Industrial Research, India is also gratefully acknowledged.

\section{Author details}

${ }^{1}$ Center for Molecular Medicine and Infectious Diseases, Department of Biomedical Sciences and Pathobiology, Virginia Tech, Blacksburg, VA-24061,
USA. ${ }^{2}$ Department of Biotechnology, College of Life Sciences, Bowling Green State University, Bowling Green, Ohio, USA. ${ }^{3}$ Central Institute of Medicinal and Aromatic Plants, Resource Centre, Boduppal, Hyderabad 500039 (A.P.), India. ${ }^{4}$ CSIR-Institute of Himalayan Bioresource Technology, Council of Scientific and Industrial Research, Palampur-176061, H. P. India.

\section{Authors' contributions}

IS and $A B$ conceptualized and designed the study with valuable inputs from $A G$, JK and PSA. IS also performed the bench work on Agrobacterium mediated transformation of a few representative recalcitrant plants using 3amino glutarimide. $A B$ drafted the manuscript. US validated the findings and conceptualized the mechanism of action of 3-amino glutarimide in Agrobacterium mediated transformation. DK carried out the Southern hybridization, SS carried out the GUS assays for the different plants and JD carried out the $\beta$-galactosidase assays. AG participated in the

conceptualization of the chemical studies. JK identified and characterized the compound formed due to autoclaving at different time intervals, NK validated the synthesis of 3-amino glutarimide through autoclaving while PD and BS participated in the validation studies. PSA convened and participated in the overall study. He also provided critical comments. All authors read and approved the final manuscript.

Received: 13 April 2010 Accepted: 31 May 2011 Published: 31 May 2011

\section{References}

1. Matsuda F, Kawasaki M, Terashima S: Efficient synthesis and antitumor activity of an enantiomeric pair of the sesbanimide $A B$-ring systems. Tetrahedron Lett 1985, 26:4639-4642.

2. Hendry LB, Muldoon TG: Actions of an endogenous anti-tumorigenic agent on mammary tumor development and modeling analysis of its capacity for interacting with DNA. J Steroid Biochem 1988, 30:325-328.

3. Harris Al: Drugs To 1984, 20:167.

4. Burzynski SR: Adv Exp Clin Chemother 1988, 6:45.

5. Corral LG, Kaplan G: Immunomodulation by thalidomide and thalidomide analogues. Ann Rheum Dis 1999, 58(1):1107-1113.

6. Sasaki K, Shibata Y, Hashimoto Y, Iwasaki S: Benzylphthalimides and phenethylphthalimides with thalidomide-like activity on the production of tumor necrosis factor alpha. Biol Pharm Bull 1995, 18(9):1228-1233.

7. Palumbo A, Miguel JS, Sonneveld P, Moreau P, Drach J, Morgan G, Einsele H: Lenalidomide: A new therapy for multiple myeloma. Cancer Treatment Reviews 2008, 34(3):283-291

8. Varala R, Adapa SR: A Practical and Efficient Synthesis of Thalidomide via $\mathrm{Na} /$ liquid $\mathrm{NH}_{3}$. Methodology. Org Proc Res Dev 2005, 9:853.

9. Kumar N, Pandey S, Bhattacharya A, Ahuja PS: Do leaf surface characteristics affect Agrobacterium infection in tea (Camellia sinensis (L.) O. Kuntze). J Biosci 2004, 29(3):309-317. 
10. Ingelbrecht I, Breyne P, Vancompernolle K, Jacobs A, Van Montagu M, Depicker A: Experimental analysis of transcriptional interference in transgenic plants. Gene 1991, 109:239-242.

11. Hiei Y, Ohta S, Komari T, Kumashiro T: Efficient transformation of rice (Oryza sativa L.) mediated by Agrobacterium and sequence analysis of the boundaries of the T-DNA. Plant J 1994, 6:271-282.

12. Ishida $Y$, Saito $H$, Ohta $S$, Hiei $Y$, Komari T, Kumashiro T: High efficiency transformation of maize (Zea mays L.) mediated by Agrobacterium tumefaciens. Nat Biotechnol 1996, 14:745-750.

13. Cheng M, Fry JE, Pang S, Zhou H, Hironaka CM, Duncan DR, Conner TW, Wan Y: Genetic transforamtionof wheat mediated by Agrobacterium tumefaciens. Pl Physiol 1997, 115:971-980.

14. Tingay S, McEIRoy D, Kalla R, Fieg S, Wang M, Thornton S, Bretell R: Agrobacterium tumefaciens mediated barley transformation. Plant J 1997, 11:1369-1376.

15. Patel M, Johnson JS, Bretell RIS, Jacobsen J, Xue G-P: Transgenic barley expressing a fungal xylanase gene in the endosperm of the developing grains. Mol Breed 2000, 6:113-123.

16. Travella S, Ross SM, Harden J, Everett C, Snape JW, Harwood WA: A comparison of transgenic barley lines produced by particle bombardment and Agrobacterium mediated techniques. Pl Cell Rep 2005, 23:780-789.

17. Murashige T, Skoog F: A revised medium for rapid growth and bio-assays with tobacco tissue cultures. Physiol Plant 1962, 15:473-4977.

18. Stachel SE, Messens E, van Montagu MV, Zambryski P: Identification of the signal molecules produced by wounded plant cells that activate T-DNA transfer in Agrobacterium tumefaciens. Nature (London) 1985, 318:624-629.

19. Stachel SE, Nester EW: The genetic and transcriptional organization of the vir region of the A6 Ti plasmid of Agrobacterium tumefaciens. EMBO J 1986, 5:1445-1454

20. Miller JH: Experiments in molecular genetics. In Cold Spring Harbor Laboratory. Edited by: Miller JH. NewYork: Cold Spring Harbor; 1972:

21. Jefferson RA, Kavanagh TA, Bevan MW: GUS fusions: $\beta$-glucuronidase as a sensitive and versatile gene fusion marker in higher plants. EMBO J 1987, 6:3901-3907

22. Doyle JJ, Doyle JL: Isolation of plant DNA from fresh tissue. Focus 1990, 12:13-15.

23. Gandini C, Lorenzi DD, Kitsos M, Massolini G, Caccialanza G: HPLC determination of pyroglutamic acid as a degradation product in parental amino acid formulations. Chromatographia 1993, 36(1):75-78.

24. Kanji A, Toshiya K, Yukifumi K: Degradation kinetics of L-alanyl-Lglutamine and its derivatives in aqueous solution. Eur J Pharm Sci 1999, 7(2):107-112.

25. Sharma RK, Chan WG, Wang J, Waymacke BE, Wooten JB, Seeman JI, Hajaligol MR: On the role of peptides in the pyrolysis of amino acids. $J$ Analytical Appl Pyrolysis 2004, 72(1):153-163.

26. Goodman JW, Klaus GG, Nitecki DE, Wang WC: Pyrrolidonecarboxylic acid at the N-terminal positions of polypeptide chains from leopard shark immunoglobulins. J Imm 1970, 104:260-262.

27. Shibata N, Yamamoto T, Toru T: Synthesis of thalidomide. Top Heterocycl Chem 2007, 8:73-97.

28. Morzyk B, Michalska D, Wojciechowski W: Interaction of metal ions with 3, 3-dimethylglutarimide. J Coord Chem 1995, 34:179-185.

29. Michalska D, Morzyk B, Bien'ko DC, Wojciechowski W: Glutarimide: a carrier transporting drug through cell membranes. Medical Hypotheses 2000, 54(3):472-474

30. Gale KE: Treatment of advanced breast cancer with aminoglutethimide. Cancer Res Supp/ 1982, 42:3389-3396.

31. Burzynski SR: Antineoplastons: biochemical defense against cancer. Physiol Chem Phys 1976, 8:275-279.

32. Kaldor SW, Hammond M, Dressman BA, Labus JM, Chadwell FW, Kline AD, Heinz BA: Glutamine derived aldehydes for the inhibition of human rhinovirus 3C protease. Bioorg Med Chem Lett 1995, 5(17):2021-2026.

33. Sandal I, Saini U, Bhattacharya A, Lacroix B, Kumar S, Ahuja PS, Citovsky V: Agrobacterium-mediated genetic transformation of tea leaf explants: Effects of counteracting bactericidity of leaf polyphenols without loss of bacterial virulence. PI Cell Rep 2007, 26:169-176.

34. Bhattacharya A, Sood P, Citovsky V: Roles of plant phenolics in defence and communication during Agrobacterium and Rhizobium infection. Mol Pl Pathol 2010, 11(5):705-719.
35. Alt-Morbe J, Kuhlmann H, Schroder J: Difference in induction of Ti plasmid virulence genes virG and virD and continued control of virD expression by four external factors. Mol Plant-Microbe Interactions 1998 2(6):301-308.

36. Godwin I, Todd G, Ford-Lloyd B, Newbury HJ: The effects of acetosyringone and $\mathrm{pH}$ on Agrobacterium-mediated transformation vary according to plant species. P/ Cell Rep 1991, 9(12):671-675.

37. Mannan A, Syed TN, Mirza B: Factors affecting Agrobacterium tumefaciens mediated transformation of Artemisia absinthium I. Pak J Bot 2009, 41(6):3239-3246

38. Hensel G, Kastner C, Oleszczuk S, Riechen J, Kumlehn J: Agrobacteriummediated gene transfer to cereal crop plants: current protocols for barley, wheat, triticale, and maize. International Journal of Plant Genomics 2009, 1-9.

\section{doi:10.1186/1472-6769-11-1}

Cite this article as: Sandal et al: Chemical modification of L-glutamine to alpha-amino glutarimide on autoclaving facilitates Agrobacterium infection of host and non-host plants: A new use of a known compound. BMC Chemical Biology 2011 11:1.

\section{Submit your next manuscript to BioMed Central and take full advantage of:}

- Convenient online submission

- Thorough peer review

- No space constraints or color figure charges

- Immediate publication on acceptance

- Inclusion in PubMed, CAS, Scopus and Google Scholar

- Research which is freely available for redistribution

Submit your manuscript at www.biomedcentral.com/submit
C) Biomed Central 